Agrosearch (2007) 9 No $1 \& 2: 1$ - 9

\title{
POVERTY AND POVERTY STATUS IN OIL PRODUCING COMMUNITIES OF ONDO STATE, NIGERIA.
}

\author{
*Apata T.G and ** Rahji, M.A.Y. \\ * Department of Agricultural Economics and Extension, J.A.BU, Ikeji-Arakeji, \\ ** Department of Agricultural Economics, University of Ibadan, Ibadan
}

\begin{abstract}
This paper examined poverty and poverty status in the oil producing communities of Nigeria; using oil-producing communities of Ondo state, Nigeria as a case study. Multi-stage sampling technique was used to collect data on economic characteristics of the household. In the first stage, oil-producing communities were identified. Three communities from coastal areas and three communities from freshwater areas were purposively selected. In each of this area, one hundred and eighty households were randomly picked. This gave the same size of 360 households and where 300 households were successfully and used for further analysis. Twentyseven percent of the households' consumed 100\% of their farm/fish output. Some $50.34 \%$ often sold less than $50 \%$ of their outputs and $22.33 \%$ sold above $50 \%$. Revenue from farming/fishing was estimated to be N159, 624.00 and loss of N175, 350.00. Households that made income losses from farming/fishing activities were $22.66 \%$ more than the number of those who did not lose. The results revealed that 60.18 percent of the households fell below the poverty line. Poverty gap index revealed $26.8 \%$ and $11.1 \%$ for severity of poverty. The majority of the identified poor households depended more on income from farming/fishing livelihood activities. The findings thus, revealed that majority of the households that do not diversified to non-farm livelihood activities were in the poor category. The different poverty levels were attributed to the intervention of oil pollution that led to decrease or loss of livelihood activities in farming/fishing, leading to poor incomes earned. Development of non farm rural activities (NFRA), education, improved health care facilities among other things are recommended as a way of alleviating extreme poverty situations in the area of study.
\end{abstract}

Keywords: Rural, poverty status, economics growth, crude oil exploitation.

\section{Introduction}

The World Bank uses household expenditure as its measuring rod while a threshold level was defined as poverty line (World Bank, 2001). In other words, people who have a household expenditure below the poverty line are defined as poor. It is a measuring rod driven by basic considerations. Accordingly people are counted poor when their measured standard of living in terms of income or consumption is below the poverty line. Thus, the poverty line is a measure that separates the poor from the non-poor.

In Nigeria, the percentage of poor declined from 1985 to 1992 (Adenuga, 1999), it later increased to 48.5 percent in 1997 and 54.2 percent in 2002 (Human Development Report, 2003). In a poverty assessment report of oil producing areas in Nigeria (between 1980-1996), United Nations Development Program (UNDP, 1998) reported an increasing trend in the incidence of poverty where about $55 \%$ of the incidence occurs. This poverty assessment result suggested the existence of a relationship between decrease (loss) in agricultural livelihood and poverty status of farmers. Since majority of the people derived their livelihood from agriculture and agricultural related activities has been attributed to the destabilizing effects of 
crude oil spills on agricultural land and incursion into surrounding freshwater. Evidence in past studies (Scherr, 1999; Bifani, 1995; IFAD, 1992 Ebisemiju, 1966) revealed that loss of livelihood in agriculture has been attributed to the destabilizing effects of crude-oil spills on agricultural land and incursion to freshwater. Thus, reducing crop yields and fishing outputs and leading to poor incomes earned.

Given the above, it is therefore important to examine the factors determining poverty and the poverty status of the people in the study area. This study uses primary and crosssectional data to examine the dimensions and status of poverty in oil-producing communities in Ondo State, Nigeria. The methodology adopted was the use of structured questionnaire using Multi-stage technique for the collection of information on the level of total household consumption expenditure and other socio-economic characteristics which might influence the occurrence of poverty in one way or the other.

\section{Concept and Nature of Poverty}

There is no general consensus on the definition of poverty in the literature (Pender $e t$ al., 2002; Okura et al., 2002). Poverty is a complex issue, which must be understood in a holistic manner. Lundgvist and Takahashi (2002) argued that it is far from enough to portray poverty in a holistic manner rather, looking into various characteristics of poverty and their relative strength determines through contextual specific circumstances can give a better picture.

Poverty is an adequate level of income and consumption that gives rise to insufficient food, clothing and shelter (Aluko, 1975). Sen (1984) looks at poverty as the lack of certain capabilities or a state of deprivation to meet a basic nutritional requirement. Poverty is one among several dimensions of deprivation that includes vulnerability, physical weakness and powerlessness (Chambers, 1995). IFAD (1992), Olayemi (1995), Scherr (1999), and Okunmadewa (1999) all argued that poverty may be defined in terms of private consumption alone, or income. Oladunni, (1999) asserted that, poverty is a condition, in which an entity is faced with economic, social, political, cultural and environmental deprivations. It is a state of involuntary deprivation to which a person, household, community or nation can be subjected to. Sen (1984) observed poor person as one who has a little money and /or a few possessions and who spent a larger proportion of his income on food consumption.

Poverty is viewed in absolute terms or relative terms depending on how it is being measured. When there is low calorie intake, poor housing condition, inadequate health facilities, and poor quality of educational facilities, also low life expectancy, high infant mortality, low income, unemployment and underemployment are all viewed as poverty situations. (Oladunni, 1999). While absolute poverty can therefore, be described as the condition of life degraded by diseases, illiteracy, malnutrition, deprivation and squalor (World Bank, 1997). Meanwhile relative poverty exists when the household have a per capita income of less than one third of the average per capita income that exists in that domain or country (Oladunni, 1999).

Barret et al, (2001) argued that adequate and more efficient implementation of poverty programmes requires greater investment of social capital to enable households to diversify into non farm rural activities and to improve on it. 
Apata and Rahji

Table 1: Administration of Questionnaire to Households in the Study Area

\begin{tabular}{l|l|l|l|l}
\hline \multicolumn{2}{c|}{ PRODUCTIONAREAS } & POPULATION & $\begin{array}{l}\text { HOUSEHOLD } \\
\text { NUMBER }\end{array}$ & $\begin{array}{l}\text { HOUSEHOLD } \\
\text { SAMPLED }\end{array}$ \\
\hline Local Govt. & Town & 18,146 & 1520 & 60 \\
Ilaje LGA & Ayetoro & 2301 & 230 & 45 \\
& Awoye & 1597 & 160 & 45 \\
Ese odo LGA & Molutehim & 10,362 & 1020 & 60 \\
& Arogbo & 2299 & 230 & 45 \\
Irele LGA & Igbekebo & 2383 & 240 & 45 \\
\hline
\end{tabular}

Source: Ondo state Demographic Variables Statistics 2000

\section{Analytical Techniques}

The analytical techniques employed in analyzing the data include the FGT approach (Food Energy Intake FEI method). This was used to obtain the food poverty line, taking a cue from the works of Foster, Greer and Thorbecke (FGT) index. FGT index was used to decompose poverty levels among the households. The analysis techniques also used were, frequency distribution and regression analysis in determining the factors influencing poverty.

\section{Analytical Techniques Procedures}

(i) Poverty and Poverty Decomposition

(a) Poverty Line: Determination

The Food Energy Intake FEI method (Greer and Thorbecke 1986; and Okurat et al; 2002) was adopted in obtaining the food poverty line in this study. This is because of its amenability to data requirements and availability.

The FEI poverty line is represented as

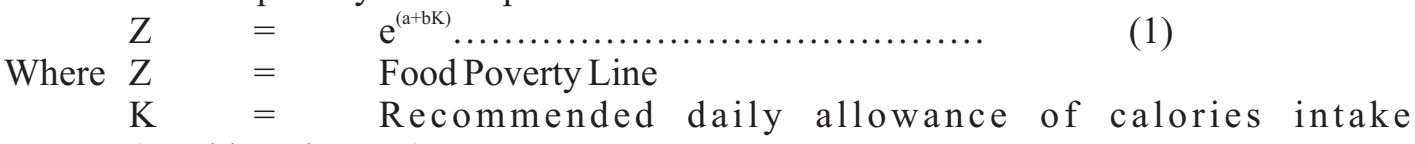
(World Bank, 2001)

$\mathrm{a}$ and $\mathrm{b}$ are estimated parameters to be obtained from equation (2) below.

$\mathrm{InE}_{\mathrm{i}}=\mathrm{a}+\mathrm{bC}_{\mathrm{i}} \ldots \ldots \ldots \ldots \ldots \ldots \ldots \ldots \ldots \ldots \ldots \ldots \ldots$ (2)

$\mathrm{E}_{\mathrm{i}}=$ total food expenditure per adult equivalent by

household i

$\mathrm{C}_{\mathrm{i}}=$ total calorie consumption for different household per adult equivalent by household

$\mathrm{a}$ and $\mathrm{b}$ are parameters to be estimated. $\mathrm{a}=$ intercept, $\mathrm{b}=$ coefficient, $\mathrm{C}_{\mathrm{i}}$ is the calorie equivalents of the different types of foods consumed by the different households converted to calories. 
Apata and Rahji

Decomposition of Poverty levels.

The Foster, Greer and Thorbecke (FGT) index, P (Foster et al; 1984) was used to decompose poverty levels among the households.

The FGT index $(\mathrm{P} \alpha)$ is given as:

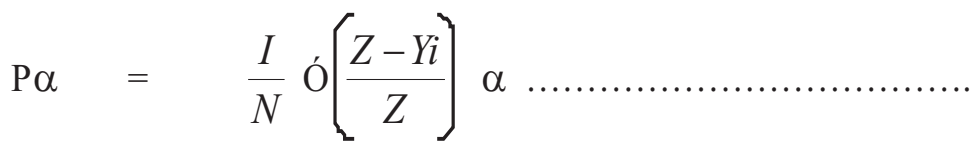

$$
\begin{aligned}
& I=\mathrm{I}
\end{aligned}
$$

Where $\mathrm{Z} \quad=$ Poverty line

$\mathrm{Y}_{\mathrm{i}} \quad=$ Income of the household $\mathrm{I}(\mathrm{I}=1,2, \ldots \ldots, \mathrm{Q})$

$\mathrm{q} \quad=$ Number of household below the poverty line

$\mathrm{N} \quad=$ total number of sampled household

$\alpha \quad=$ parameters of the FGT index ( $\mathrm{P} \alpha)$. $\mathrm{a}=0$ and it can take three Values of 0,1 and 2 . These values give different implications.

\section{Implications}

If $\mathrm{a}=0$, Po measures poverty incidence. If $\mathrm{a}=1, \mathrm{P}_{1}$ measures the poverty depth of the households. This denotes the proportion of the poverty gap that the average poor will require to get to the poverty line. If $\mathrm{a}=2, \mathrm{P}_{2}$ measures the severity of poverty. This gives more weight to the poorest of the household poverty.

The FGT index $(\mathrm{P} \alpha / \alpha=0,1,2)$ ranges between zero and one. The closer the FGT index is to one, the greater the poverty level. The FGT index has been widely used to determine level of poverty (Greer \& Thorbecke, 1986; Aigbokhan, 2000; Okurat et al; 2002). Generally, the higher the Po, the worse the poverty situation. Similarly, the higher the $\mathrm{P}_{1}$ value the greater is the depth of poverty. In the same vein; the higher the $\mathrm{P}_{2}$, the more severe poverty situation.

\section{Determination of the Factors Influencing Poverty}

A functional relationship was formulated to ascertain the determinants of household per capita expenditure on basic needs and other factors using regression analysis. The implicit form of the equation is stated as

Alinear equation was chosen as the lead equation. This is as follows:

$$
\mathrm{Y}=\alpha+\hat{\mathrm{a}}_{1} \mathrm{X}_{1}+\hat{\mathrm{a}}_{2} \mathrm{X}_{2}+, \ldots \ldots,+\hat{\mathrm{a}}_{13} \mathrm{X}_{13}+\mathrm{a} \mathrm{a}
$$

Where $\mathrm{Y}=$ the dependent variable (per capita expenditure on basic needs per year)

$\begin{array}{lll}\alpha & = & \text { Constant term } \\ \hat{\mathrm{a}}_{1}-\hat{\mathrm{a}}_{13} & = & \text { Regression coefficients } \\ \mathrm{X}_{1}-\mathrm{X}_{13} & = & \text { Independent variables. } \\ \mathrm{a} t & = & \text { Error term }\end{array}$


It is hypothesized that the following factors are significant in explaining poverty; Adjusted household size $\left(\mathrm{X}_{1}\right)$ number, Level of education $\left(\mathrm{X}_{2}\right)$ in years, Age $\left(\mathrm{X}_{3}\right)$ in years, Farming/fishing experience $\left(\mathrm{X}_{4}\right)$ in Naira, Hired labour $\left(\mathrm{X}_{5}\right)$ in Naira, Farming/fishing input $\left(X_{6}\right)$ in Naira, Opportunity cost of own labour $\left(X_{7}\right)$ in Naira, Farming/fishing income $\left(X_{8}\right)$ in Naira, Farm size $\left(\mathrm{X}_{9}\right)$ in Hectares $(\mathrm{Ha})$, Non-farm Rural Activities Income $\left(\mathrm{X}_{10}\right)$ in Naira, Income Consumed Outputs $\left(\mathrm{X}_{11}\right)$ in Naira, Access to extension facilities $\left(\mathrm{X}_{12}\right)$ Dummy, if access $=1$, otherwise $=0$ and Access to credit facilities $\left(X_{13}\right)$ Dummy, if access $=1$, otherwise $=0$, Basis for the selection and use of these variables are economic theory and previous/similar studies.

\section{Results and Discussion}

The percentage of illiterate persons in the studied area (21\%) implied that the average household head was educated. A further analysis revealed that the majority of household heads whose heads were not literate were poor. There was significant difference in the poverty status of households according to the different levels of educational attainment. The lower the educational level of the household head, the greater the proportion of poor households within the sample. This finding seems to support the fact that a certain minimum level of education is essential for increasing household productivity and income earning potential as evidenced by Grootaert, (1997).

\section{Distribution of the Households Head's Income.}

The income of a household is a function of the number of persons working in the household and sometimes the level of educational attainment (Scherr, 1999). Income is a determinant of household expenditure since it serves as the budget constrains to the amount that can be spent within a period, there is also correlation between income and poverty level of a household, all other thing being equal. Table 1 describes the distribution of household heads by the levels of their income.

Table 1: Percentage distribution of households by income groups

\begin{tabular}{l|c|c}
\hline INCOME GROUP $(\mathbf{N})$ & RESPONDENT $(\mathbf{N})$ & PERCENTAGE \\
\hline Below 15,000 & 35 & 11.67 \\
$15,00030.000$ & 52 & 17.33 \\
$30,00145.000$ & 48 & 16.00 \\
$45,00160.000$ & 95 & 31.67 \\
$60,00175.000$ & 58 & 19.33 \\
Above 75.000 & 12 & 4.00 \\
\hline Total & $\mathbf{3 0 0}$ & $\mathbf{1 0 0 . 0 0}$ \\
\hline
\end{tabular}

Source: Field Survey 2006

The annual per capita income was between N 9500 and N 14500 . About $45 \%$ of the respondents earned per capita income that was below or equal to $\mathrm{N} 45000$ (equivalent of less than $\mathrm{N} 4000$ per month). This range was less than minimum wage of the government workers in Nigeria. 
Apata and Rahji

\section{Poverty and Poverty Decomposition}

Analysis of the FGT measures of poverty is presented in Table 2. These measures quantified the three measures of poverty, namely the level, the depth and the severity of poverty. The headcount ratio $(\mathrm{Po})$ is the ratio of the number of poor individuals to the total population. The results revealed that Awoye had the highest headcount ratio (Po) $(66.67 \%)$ of the sampled households falling below the poverty line. This was followed by Ayetoro 63.3 percent, and Igbekebo 62.2 percent. The poverty gap index, $\mathrm{P}_{1}$, also reflects that Awoye has the greatest depth of poverty of 37.5 percent. The severity of poverty captured by $\mathrm{P}_{2}$ also suggests that Awoye 19.4 percent, Ayetoro 17.3 percent and Igbekebo 16.8 percent have severe poverty. The overall poverty profile revealed that 60 percent of the households fall below the poverty line (Table 3 ) while poverty gap revealed 26.8 percent and 11 percent of severity.

Table 2: Poverty Levels Estimates Based on Food Poverty Line for the Areas

\begin{tabular}{l|c|c|c}
\hline TOWN & PO & $\mathbf{P}_{1}$ & $\mathbf{P}_{2}$ \\
\hline Iju-Osun & 0.5561 & 0.1358 & 0.0832 \\
Arogbo & 0.5328 & 0.1721 & 0.0974 \\
Igbekebo & 0.6222 & 0.3092 & 0.1878 \\
Ayetoro & 0.6331 & 0.3284 & 0.1730 \\
Molutehim & 0.5769 & 0.2869 & 0.1572 \\
Awoye & 0.6671 & 0.3750 & 0.1350 \\
\hline Total & $\mathbf{0 . 6 0 1 8}$ & $\mathbf{0 . 2 6 7 8}$ & $\mathbf{0 . 1 1 0 7}$ \\
\hline
\end{tabular}

Source: Computed from Poverty Line Measures

Ebisemiju (1966) reported that Ayetoro and Awoye towns in the 50's and 60's were noted for high fish marketing and fish products. These two towns that dominated the then Igbokoda International fish market at these periods. Fish sector was where the majority derived their livelihood and over 91 percent of household's earned income from this source (Ebisemeju, 1966). The advent of crude oil exploration in 1973 and its effects started to manifest in the early 90s (Ondo State Economic Summit, 2001). It culminated to the loss in fish yield and declining income from fishing activities. The results of all the three measures of poverty further suggest that poverty situation has worsened in the study area. This implies that for household to move out of poverty, farming or fishing cannot be considered as the primary source of income generation.

\section{Determination of the factors affecting the per capital expenditure (Poverty level)}

The regression analysis result suggests that per capita income from non farm income; farming/fishing experience and access to credit were positively and significantly related to per capita expenditure while the other three variables (adjusted household size, income from farming/fishing and income consumed at home) were negative and significantly related. This suggests that, access to credit facilities and the participation in non farm livelihood activities, more money will be available to the household to meet basic needs. The negative relationship between the adjusted household size, income from farming/fishing and income consumed 
outputs at home explained the less per capita food expenditure (that is if the number of people working in the household is relatively small compared to the total numbers according to Nwaobi, 2004). Income from farming/fishing and income consumed outputs at home variables has negative signs. These variables indicated reduction in money that will be available for household needs. Farming/fishing income and income consumed outputs at home though significant at 5\% but were negatively related. This thus, suggests that the more of these variables the less the per capita income. The relatively low $\mathrm{R}^{2}$ may be due to non-inclusion of certain variables, which range from quantitative to qualitative ones.

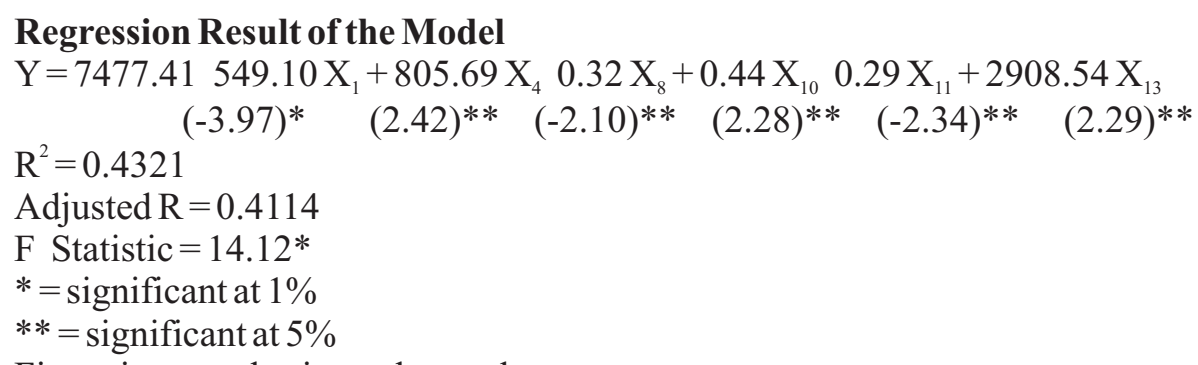

Figure in parenthesis are the $t$ values

NB: Four functional equations were tried, but the linear equation gave the highest number of significant variables in addition to the Multiple of Determination Variable $\left(\mathrm{R}^{2}\right)$. Thus, the linear equation was taken as the lead equation and used for results presentation.

\section{Conclusion}

The analysis of poverty level computed based on poverty line revealed a high prevalence with more than half of the rural households (66.67\%) being below the poverty line and spreads across all towns studied. There are other socio-economic variables identified as the determinants of poverty. Households who were poor in this area constituted about $60.20 \%$ who depended more on farming/fishing livelihood activities. This result agreed with Quibria and Srinivasan (1991). In addition findings from this study revealed that investment in farming and fishing was no longer financially rewarding as it increases the likelihood of poverty. It is therefore suggested that there is a need for a broad range of review of agricultural development, infrastructural enhancement efforts, diversification programmes and marketing opportunities. Results from the socio economic variables revealed that majority of the households that had low/no education were poor. Those households that had high education and they are non-poor. This calls for policy for improving access to education by the poor households. Skills enhancements training need be develop in this area to enable households to take advantage of available business productive opportunities.

\section{References}

Adenuga .A.O. (1999) "Petroleum industry and Environmental protection in Nigeria experience". $C B N \quad$ Bullion 23.4:95-102

Aigbokhan, B.E 2000. "Poverty, Growth and inequality in Nigeria a case study" African Economic Research Consortium Research Paper102 October. $\quad 72 \mathrm{pp}$ 
Apata and Rahji

Aluko, S. 1975." Poverty-its Remedies" Journal of the Nigerian Economics Society 4. 2:361370

Bardhan, P.K. 1973. "On the Incidence of Poverty in Rural India”. Economic and Political Weekly, March, 1973. Effects and control”(eds) Roy, M.Harrison, G. Whitsable Litho Ltd., London. 342pp

Barret, C.B., T. Reardon and P. Webb 2001. "Non-farm income diversification and household Livelihood strategies in rural Africa" Concepts, Dynamics and Policy implications. Food policy. 26. 4:315-331

Bifani,P.1995. Environmental degradation in rural areas, cited in The Environment, Employment and Development Work edited by Bhalla, ILO office Geneva.Chapter 2:154-301

Chambers, R. 1995. Poverty and livelihoods: Whose reality counts? IDS discussion 347:1- 67

Echebiri, R.N. 1997:" The Structure of Income, inequality and Poverty in Rural Southern, Nigeria".Proceedings of the 1997 Annual Conference of the Nigerian Economy

Ebisemiju,F.S. 1966."The fishing economy of Ilaje District" B.A. Project in the Department of Geography, University of Ibadan.(unpublished) $187 p p$

Ebisemiju,F.S. 1990"The environmental consequences of Transport and resource development in the Coastal areas of Ondo state. Journal for economics and Social Statistics, 32. 2:141-157

Ellen,W. 2001. "Famine and Poverty in the $21^{\text {st }}$ century. Unfinished Agenda IFPRI publication (2002) for IFPRI's 2020 vision initiatives. Chapter 4: 114-167 Federal Office of Statistics FOS 1997." National consumer survey 1996/97. preliminary repots, 1-208

Foster, J., J.Greer and E. Thorbecke 1984. A class of Decomposable Poverty Measure. Econometrical 52.2:761-766

Greer, J. and E. Thorbecke 1986. A methodology of measuring food poverty, Applied to Kenya. Journal of Development Economics, 24 (2): 59-74.

Grootaert,C. 1997. " The determinants of Poverty in Cote d'ivorie in the 1980s. Journal of African Economies, 6(2):169-196

IFAD, (1992) Oil and water conservation in Sub-Saharan Africa: Towards Sustainable Production by the Rural poor. A report prepared for the International fund for Agricultural Development. Center for Development Co-Operation Services, Free University Amsterdam Holland.

Lundgvist, J. and K. Takahashi 2002. Water, Poverty alleviation and Social programs. Workshop Paper presented at Stockholm water symposium annual meeting A u gus $t$, Sweden. Workshop paper 3: 112-167

Niger-Delta Development Commission NDDC 2002 Reports of findings on Project assessment tour of all Niger-Delta areas, November.

Ogwumike,F.O.(1987)"Poverty and Basic needs. An approach to Development in Nigeria". Ph.D. Thesis in the Department of Economics University of Ibadan. (Unpublished).

Okunmadewa, F.1999. International Agencies response to poverty situation in Nigeria ". CBN Bullion 23 (4): 66-70

Okunmadewa, F.2003 "Risk and Vulnerability in Agriculture: concept and Context" Staff seminar paper in the Department of Agricultural Economics, University of Ibadan, December $5^{\text {th }}$ 
Apata and Rahji

Okurat, F.N., J.O. Odwee and A. Adesina 2002:" Determinants of regional poverty in Uganda: African Economic Research Consortiums AERC RP 122:1-87

Oladunni, E.B.I.1999.The dimensions of poverty in Nigeria: Spatial, Sector, Gender In ". CBNBullion 23 (4): $\quad$ 17-30

Olayemi, J.K. 1995. The design of a poverty alleviation program for Nigeria Working paper for Poverty Alleviation Program development committee, National Planning commission, Lagos July 1995.

Ondo State Demographic Statistics 2000. Compiled by Ondo StateMinistry of information,

Ondo State Economic Summit 2001.Published by Ondo State Ministry of Information

Ondo State Environmental Action Plan 1998. Published by Ondo State Ministry of Information

Ondo state Poverty study group 1995. Published by Ondo State Ministry of Information

Ondo State Economic Reports, 2003 :Blueprint on Massive Food Production.

Pender,J.P., P.Hazell and J.L.Garret 2002.'Reducing poverty and protecting the environment. The overlooked potential of less-favoured lands Unfinished Agenda

IFPRI publication (2002) for IFPRI's 2020 vision initiatives.

Quibria, M.G and J.N. Srinivasan 1991. Rural poverty in Asia: Priority issue and policy options. Manila: Asian Development Bank, Mimeo.

Scherr, S. J. 1999. Poverty Environment Interactions in Agriculture: Key factors and policy implications.Paper prepared for the United Nations Development Programme UNDP.

Sen, A. 1984. "Rights and capabilities".In Sen, A. Resources, Values and Development, Basil Blackwell publishers, oxford

United Nations Development Programme UNDP 1990, 1998 \& 2003. Human Development Reports Nigeria Oxford University Press Nigeria

World Bank (1996)"Poverty assessment in the midst of plenty. The challenge of growth with inclusion in Nigeria". World Bank Poverty Assessment, May $31{ }^{\text {st }}$ Washington D.C

World Bank 1997. Pollution, prevention and abatement handbook, toward cleaner production (annual meetings edition). The World Bank group in collaboration $\mathrm{w}$ i t h U N E P, UNIDO and WHO September, 1997.

World Bank (2001): Global Economic prospects and the Developing countries www.worldbank.org March, 2000

World Bank Environment and strategy (2000): Poverty and Environment ww.worldbank.org February, 2000

Zannin, G., A. Berti and M. Giannini 1992. Economics of herbicide use on arable crops in north central Italy. Crop protection, 11(2):153-159 